Walisongo Law Review (Walrev), Vol 2 No. 2 (2020)

DOI: 10.21580/walrev/2020.2.2.6587

Copyright (C) 2020 Walisongo Law Review (Walrev)

\title{
Sishankamrata in the Indonesian State Defense and Security System from the Beginning of Independence to the Reform Period
}

\author{
Ladlul Muksinin \\ Afiliasi: Universitas Diponegoro, Semarang \\ e-mail: ladlulmuksininvivo@gmail.com
}

\begin{abstract}
The debate regarding the concept of the Indonesian state defense and security system is still a fundamental subject of mathematic since the independence era until the reform era. For example, regarding the definition of national security with state security, defense function with security functions, regulations, and many more. For this reason, this paper will discuss how the dynamics of the Sishankamrata in the State Defense and Security System (Sishanneg) the independence era the reform era. This paper discusses that the National Defense System (Sishaneg) is believed to still need to be maintained in national defense and security policies. The concept of Sishankamrata develops its form of defense through the involvement of all components of the citizenry, territorial integrity, natural resources, and other means that have been prepared in advance. This system also makes defense integration (military and non-military) stronger, more respected, and has higher deterrence. So that in the era of reform, it was explicit that the concept of Sishankamrata was considered powerful enough so that it was still maintainedExplicitly in the reform era after the amendment of the 1945 Constitution of the Republic of Indonesia, the concept
\end{abstract}


Ladlul Muksinin, Sishankamrata in the Indonesian State Defense...

of Sishankamrata was still maintained and wa considered quite effective.

Perdebatan mengenai konsep sistem pertahanan dan keamanan negara Indonesia masih menjadi problematika mendasar sejak masa kemerdekaan hingga masa reformasi. Misalnya mengenai pengertian keamanan nasional dengan keamanan negara, fungsi pertahanan dengan fungsi keamanan, regulasi dan masih banyak lagi. Untuk itu tulisan ini akan mendiskusikan bagaimana dinamika Sistem Pertahanan Keamanan Rakyat Semesta (Sishankamrata) dalam Sistem Pertahanan dan Keamanan Negara (Sishanneg) dari awal kemerdekaan pasca reformasi. Tulisan ini akan mendiskusikan bahwa Sistem Pertahanan Nasional (Sishaneg) perlu untuk tetap dipertahankan dalam kebijakan pertahanan dan keamanan nasional. Konsep Sishankamrata ini mengembangkan bentuk pertahanannya melalui keterlibatan seluruh komponen warga negara, kesatuan wilayah, sumber daya alam, serta sarana lainnya yang lebih dulu dipersiapkan. Sistem ini juga melakukan integrasi pertahanan (militer dan nirmiliter) menjadi lebih kuat, lebih disegani, dan lebih tinggi daya tangkalnya. Secara eksplisit pada era reformasi setelah UUD NRI Tahun 1945 diamandemen, konsep Sishankamrata ini masih dipertahankan dan dianggap cukup efektif.

Keywords: National Security System; Sishankamrata; National Security Law

\section{Introduction}

The background of success in the life of the nation and state lies in two factors, namely prosperity, and security. Hikam explained that the success of the "security" sector is the basic capital for economic development for the sake of "welfare", as well as in increasing "welfare" demands success in the "security" sector (Hikam, 2018: 2). According to Hidayat, both welfare and security are intertwined or intermestic (Hidayat and others, 2017: 120). As a fundamental need 
for the people, proper policies and regulations are needed in line with the development of various threats in the era of globalization.

One of the highlights of the demand for national reform and the topic that we will examine is reform in the defense and security sector. The reform of the defense and security sector raises various new problems, for example, debates on the definition of national security with state security, defense functions with security functions, regulations and ministries in charge that are still not synchronized, and many more (Sukmadi, 2010: 3). So to answer these problems requires appropriate steps, for example, an in-depth analysis of the state environment is needed regarding ideological, political, economic, social, and cultural developments at the domestic, regional, and international levels (Witarti and Armandha, 2018: 88). Furthermore, a structured agenda is needed in building and increasing synergy within the government to realize the right direction and targets for defense and security (Alfajri, Setiawan, and Wahyudi 2019: 104). However, this defense and security reform must still be based on the national doctrine and philosophy (Mukhtar, 2017: 134).

Developments regarding strategic issues such as globalization, the industrial revolution, democratization, humanity, radicalism, and terrorism have expanded the scope of increasingly complex threats. (Susetyo, 2008: 2). So the development of threats is not only seen from the military but also from the security of other threats, for example, the increase in asymmetric crime, cybercrime (Ardiyanti, 2016: 107), wiretaps from other countries (Luthfah, 2016: 330), threats to human security (Anggoro, 2003: 2) and there are many others that our current national defense and security system has not been able to accommodate.

Based on the background description above, in this case, the author must discuss the dynamics of the Universal People's Defense and Security System (Sishankamrata) in the State Defense and Security System (Sishankamneg) in the State of Indonesia from the beginning of independence era to the reform era. 


\section{Discussion}

\section{State Defense System (Sishaneg)}

To understand the National Defense System (Sishaneg), we can see the terminology in Article 1 paragraph (2) of Law Number 3 of 2002 concerning State Defense. Described in it, Sishaneg is a system that is "universal", where the implementation is carried out in a total, integrated, directed, and the continuous manner by involving "all citizens", "territories", and "other national resources" which have been deliberately prepared from scratch. to "uphold national sovereignty", "national territorial integrity", and "the safety of the entire nation from all threats".

Based on the mandate of Article 30 paragraph (2) of The 1945 Constitution of The Republic of Indonesia, in which efforts in implementing defense and security must comply with the Universal People's Defense and Security System (Sishankamrata) by the Indonesian State Personnel (TNI) and National Police (Polri) as the "main force" and the people as the "supporting force". Here we know that the government already has two institutions that work in defense and security (Jazuli, 2016: 190), however, they still need the strength of the Indonesian people for the success of this task (Saputra and others, 2019: 23). The implementation of the mandate of Article 30 has been realized in the form of laws and regulations, namely Law Number 3 of 2002 concerning State Defense, Law Number 2 of 2002 concerning the National Police, and Law Number 34 of 2004 concerning Indonesian State Personnel Number 34 of 2004 concerning Indonesian State Personnel. However, the problem of the Law on the "security concept" is that it can be drafted with Law Number 3 of 2002 concerning State Defense to improve the People Defense and Security System (Sishankamrata) (Nakir, 2015: 15).

The Sishankamrata operation patterns are the defense operation pattern, the domestic security operation pattern, the strategic intelligence operation pattern, and the Southeast Asia defense and security cooperation operation pattern (Suwito, 2017: 141-142). 
Therefore, the Indonesian state needs to have a national defense system that is universal. This is Sishankamnas which is the milestone and doctrine of national defense.

The concept of Sishankamrata develops its form of defense through the involvement of all components of the citizenry, territorial integrity, natural resources, and other means that have already been prepared. This system makes defense integration (military and nonmilitary) stronger, more respected, and has higher deterrence (Pertahanan, 2015: 28).

The nature of "being prepared early" means that this Sishankamrata has been prepared from the beginning and is ongoing to face various types of threats that come. The nature of "universal" is meant for the involvement of the nation because it has awareness of the "rights and responsibilities of the people" and the belief in "protecting and maintaining" the survival and integrity of the territory of the Republic of Indonesia which is led by the state (under the Ministry of Defense).

The function of organizing Sishaneg is not only to deal with external military threats but also conflicts from within (Indrawan, 2015: 84-96). For that, we need awareness, a sense of responsibility by every citizen based on his belief in his strength and an unyielding spirit (Rosikin, 2010: 23).

Until now, Indonesia has adhered to the National Defense System (Sishaneg) which is believed to still need to be maintained. Sishaneg was chosen and became the only "system" in national defense and security policy. The characteristics of Sishaneg are also not much different from Sihankamrata, namely the "typical" system of National defense politics. As for the characteristics of Sishankamrata, namely, democracy, universality, and territory (Kennedy, 2017: 71). The explanation of "populist" characteristics shows that people's interests are the main objective, "universality" includes all national resources, and "territorial" covers the entire territory of the Republic of Indonesia, both domestic and regional threats (Yanti, 2014: 19). 
As we know, in Article 1 paragraph (3) of The 1945 Constitution of The Republic Of Indonesia, Indonesia is a state of law (rechtstaat) in the meaning of "the rule of law" and not a state of power (macthsstaat) in building the life of the nation and state. (Siallagan, 2016: 131). According to Jimly Asshiddiqie, the concept of a rule of law places only law as the commander in the dynamics of the state. (Asshiddiqie 2011). So to realize a rule of law, an orderly civic law is needed (Wijayanti, 2016: 185). According to Ni'matul Huda, he emphasized the need to pay attention to the hierarchy where every statutory regulation that is made must pay attention to the higherlevel laws and regulations (Huda, 2006: 27-28). The following is a hierarchy of laws and regulations that are used as a legal umbrella in implementing Sishankamrata in Indonesia, namely:

a. The preamble to The 1945 Constitution of The Republic Of Indonesia (the constitution), in which it regulates the state's obligations and the main objectives of national defense and security, namely to "protect" the entire nation and "protect" all the blood of Indonesia.

b. Article 30 paragraph (1) of The 1945 Constitution of The Republic Of Indonesia, which regulates how the strategy, basis, and components of the security system.

c. Law Number 2 of 2002 concerning the National Police.

d. Law Number 3 of 2002 concerning State Defense.

e. Law Number 34 of 2004 concerning Indonesian State Personnel.

f. Law Number 23 of 2019 concerning Resource Management for National Defense.

\section{Development of Post-Independence Sishankamrata}

Sishankamrata developed in Indonesia since the beginning of the struggle of the Indonesian nation after the proclamation of independence in 1945. The spirit of struggle to maintain the country's independence and sovereignty was the forerunner of Sihankamrata. The struggle was continued afterward by carrying out operations to 
restore national security, especially in rebellions, separatist movements, and other security disturbances. So based on the experience of the nation's struggle, the state compiled the doctrine of Defense and Security for the Universal People (Hamkamrata) and succeeded in being ratified in 1982 through Decree of the Minister of Defense and Security Number Skep/820/VII/1982 dated 12 July 1982. Furthermore, Law Number 20 of 1982 was passed made Sishankamrata the system for administering the State Defense and Security Agency.

Hankamrata itself presumes that Sishankamrata is capable of involving the people as a whole and shifting the thermology that the state is not the only party responsible for running the state. Even though the classification of our national security component consists of a basic component of the Trained People, a special component for Community Protection, it is considered less successful (Gunawan, 2011: 161). So it is necessary to implement a proper implementation by making the responsibility of national defense and security into an integrated responsibility concept (Manggala, 2016: 77).

Sishankamrata's "universality" strives to create conditions for national security in a very broad sense, covering various components to maintain stability and survive dynamic developments in all aspects of the life of the nation and state.

During the New Order era, Sishankamrata was an embodiment of efforts to organize the State Security Defense to achieve national goals through Law Number 20 of 1981 where this system regulates the priorities of the "ABRI" Trained People as a basic component and Community Protection as a special component (Indarti, 1994: 1-3). Sishankamrata is considered the key to the success of ABRI in security operations, for example in the strategy of forming militias in anti-rebellion military campaigns (separatism). (Kontras, 2006: 41). The understanding of ABRI at that time was built through a doctrine called Catur Dharma Eka Karma (Cadek) in 1988 to become a selfcreating entity. Apart from that, ABRI is also an institution that is unified with the people, where the success of its military operations is 
determined by the active participation of all the people (Widjajanto, 2014: 12-13). Although in the end many thought that the operation was violent.

According to Reza, the formation of militias, which were also secretly supported by ABRI based on the concept of the Sishankamrata, increased public attention to human rights violations in non-international armed conflicts. He continued, Sishamkamrata is a major national defense strategy adopted based on the state's experience during the physical revolution of "armed war" in the struggle for independence of the Republic of Indonesia (1945-1949) which was later recognized in the second amendment of The 1945 Constitution Of The Republic of Indonesia (Reza, 2017: 155).

Meanwhile, Article 4 paragraph (1) of Law Number 20 of 1982 states that the Sishankamrata doctrine places the "people" as the source of national defense, at which time the Sishankamrata doctrine itself is being proposed to be included in the amendment of the 1945 Constitution of the Republic of Indonesia to the Article on State Defense carried out by the Ad-hoc Committee I of the People's Consultative Assembly (MPR) Worker Agency. This has great potential for military violence against the people themselves, including: first, the loss of the guarantee for the immunity rights of the "people" in the Geneva Conventions. Second, the proportionality requirement (loss calculation) is ignored, where the "universality" character has full authority to the military to explore resources for the sake of war, even though this is a natural thing during war. Third, the authority to declare war by a "democratic" government is not absolute (Widjajanto, 2014: 14).

\section{Post-Reformation Sishankamrata Development}

In the reform era after the amendment of the 1945 Constitution of the Republic of Indonesia, it was explicit that the concept of Sishankamrata was considered powerful enough so that it was still maintained. Although it is still maintained, there will still be a shift in the concept regarding the separation of the Police from the TNI and 
their respective duties and a change in terminology from Sihaneg to Total Defense as mandated by Decree of the People's Consultative Assembly (Tap MPR) Number VI and VII of 2000 (Samego, 2018: 3). According to Bambang, the two MPR decrees contain fundamental problems, namely, (1) there is a black and white concept of defense and security which has implications for regional sovereignty and integrity, (2) there is a narrowing of the meaning of security in police duties to become less comprehensive. (Darmono, 2010: 20). But on the other hand, it must be acknowledged that the two MPR decrees became the starting point in the overhaul of the security system in this reform era. (A'raf Al A'raf, 2015: 35; Prihatono, 2006).

In this reform era, people's participation as a reserve component (if there is no war) has shifted, so the implementation of state defense where the focus is more on defending the "non-physical" state to shape the noble character and personality of the nation's children. (Umra, 2019: 177).

Then also clear legal regulations are needed to build an integrated security concept through the National Security Bill Nasional (Djuyandi, 2014: 456). During the era of President Susilo Bambang Yudhoyono (SBY) the discussion of the National Security Bill had stalled. Furthermore, in the era of President Joko Widodo, to be precise in 2014 the discussion was resumed and would even be included in the National Legislation Program (Prolegnas) in 2015 by the Chairman of Commission I DPR, who was then held by Mahfudz Siddiq. However, according to Mahfudz, careful thinking is needed so that mistakes will not be repeated. The National Security Bill is still being debated both in the legislature and in the community because of a tug of war between the TNI and the Police which has the potential to threaten national security which is multidimensional (Setyadi 2014; Simanjuntak 2020; Wulandari et al. 2020).

Based on Article 3 of the National Security Bill, it is stated that the objective of implementing National Security is to "create a safe condition for the nation and the Unitary State of the Republic of Indonesia physically and psychologically for every individual citizen, 
society, government, and state, to protect national interests "(to realize a safe condition for the nation and the Unitary State of the Republic of Indonesia physically and psychologically for every individual citizen, society, government, and state, to protect national interests)". These national security objectives are needed together with the objectives of the Defense Law to protect the existence of the state and its citizens from internal and external threats.

Article 5 of the National Security Bill states that the scope of national security includes human security, public security, internal security, and external security. Each scope is explained based on its scope. Human security is stated in Article 6 of the Bill on National Security where responsibility leads to joint efforts as an effort to protect basic human rights. Public security is stated in Article 7 of the Bill on National Security, where the responsibility goes to the Police as an effort to maintain security and security. Internal security is stated in Article 8 of the Bill on National Security where responsibility is directed to the TNI as an effort to maintain territorial integrity and sovereignty. Finally, external security is stated in Article 9 of the National Security Bill, where the responsibility is directed to the TNI as an effort to prevent and suppress military threats. These are the basic provisions that give authority to both the state apparatus, both the TNI and Polri, as an effort to maintain national security.

The merger of defense and security functions in the National Security Bill has become a tug of war between TNI and Polri. The reason is that the defense and security functions which were previously separated based on the authorities stated in both the TNI Law and the Police Law have been merged again. This has the potential to raise new problems and make the relationship between the TNI and Polri sharpen again. The provisions referred to are Article 5 of the TNI Law which states, "The TNI acts as a state instrument in the defense sector..." and Article 2 of the National Police Law states, "The police function is one of the functions of the state government in the field of maintaining public security and order...". 
The clear mention of the TNI and Polri is contained in Article 20 of the National Security Bill on the National Security Bill which states that the TNI and Polri are elements of national security administrators along with other non-ministerial state institutions including the Ministries referred to in Law No. 39 of 2008 concerning the State Ministry, the Attorney General's Office, the State Intelligence Agency (BIN), the National Disaster Management Agency (BNPB), the National Narcotics Agency (BNN), the National Counterterrorism Agency (BNPT), and other non-ministerial government agencies.

Based on data obtained from the DPR RI page, the progress of the National Security Bill since 2013 is still being discussed at the second level of discussion (DPR, 2020). However, the public hopes that it will soon be passed and become an umbrella for security law along with the National Defense Law.

To conclude, Sulistiyo explained that there are at least five "main objectives" included in the national security policy which is integrated and detailed, namely as state guarantee from all forms of threats, increasing the effectiveness and optimization of security administration, as a guideline for its implementation, as a means of domestic consensus, and increase trust (trust) and security cooperation (security relations) (Sulistyo and others, 2009: 168).

According to Barry Buzan, the national security policy is said to be successful (guaranteed) if the state can properly integrate military strength, economy, advanced technology, political stability, and integrated social life. (Buzan, 2008; Hermawan, 2007: 35). Indirectly, the national security policy will become a means and lead the country to increase national welfare.

\section{Conclusion}

Indonesia adheres to the National Defense System (Sishaneg) which is believed to still need to be maintained. Sishaneg was chosen and became the only "system" in national defense and security policy. The characteristics of Sishaneg are also not much different from the 
Universal People's Security Defense System (Sihankamrata), namely the "typical" system of National defense politics. The concept of Sishankamrata develops its form of defense through the involvement of all components of the citizenry, territorial integrity, natural resources, and other means that have been prepared in advance. This system makes defense integration (military and non-military) stronger, more respected, and has higher deterrence. Sishankamrata developed in Indonesia since the beginning of the struggle of the Indonesian nation after the proclamation of independence in 1945. So based on the experience of the nation's struggle, the state compiled the doctrine of Defense and Security for the People of the Universe (Hamkamrata) and succeeded in being ratified in 1982. Explicitly in the reform era after the amendment of the 1945 Constitution of the Republic of Indonesia, the concept of Sishankamrata was still maintained and was considered quite effective. [w]

\section{References}

A'raf Al A'raf, Al. 2015. "Dinamika Keamanan Nasional." Jurnal Keamanan Nasional 1(1):27-40.

Aceh, Kontras. 2006. Aceh Damai Dengan Keadilan, Mengungkap Kekerasan Masa Lalu. Jakarta: Kontras.

Alfajri, Alfajri, Azhari Setiawan, and Herry Wahyudi. 2019. "Sinergitas Pembangunan Tata Ruang Pertahanan Daerah Dalam Menghadapi Ancaman Non-Militer Di Indonesia." Global Strategis 13(1):103-22.

Anggoro, Kusnanto. 2003. "Keamanan Nasional, Pertahanan Negara, Dan Ketertiban Umum." in Seminar Pembangunan Hukum Nasional VllI. Denpasar: Badan Pembinaan Hukum Nasional, Departemen Kehakiman dan HAM RI.

Ardiyanti, Handrini. 2016. "Cyber-Security Dan Tantangan Pengembangannya Di Indonesia." Jurnal Politica Dinamika Masalah Politik Dalam Negeri Dan Hubungan Internasional 5(1). 
Asshiddiqie, Jimly. 2011. "Gagasan Negara Hukum Indonesia." in Makalah Disampaikan dalam Forum Dialog Perencanaan Pembangunan Hukum Nasional yang Diselenggarakan oleh Badan Pembinaan Hukum Nasional Kementerian Hukum dan.

Buzan, Barry. 2008. People, States \& Fear: An Agenda for International Security Studies in the Post-Cold War Era. Ecpr Press.

Darmono, Bambang. 2010. "Konsep Dan Sistem Keamanan Nasional Indonesia.” Jurnal Ketahanan Nasional 15(1):1-42.

Djuyandi, Yusa. 2014. "Politisasi Kebijakan Dalam Rancangan Undang-Undang Keamanan Nasional.” Humaniora 5(1):455-67.

Gunawan, Kazan. 2011. "Human Security Dalam Negara Demokrasi: Perspektif Media Studies.” Jurnal Kawistara 1(2).

Hermawan, Yulius Purwadi. 2007. Transformasi Dalam Studi Hubungan Internasional: Aktor, Isu Dan Metodologi. Jakarta: Graha Ilmu.

Hidayat, Safril and others. 2017. "Kebijakan Poros Maritim Dan Keamanan Nasional Indonesia: Tantangan Dan Harapan." Jurnal Pertahanan \& Bela Negara 7(3):89-104.

Hikam, Muhammad A. S. 2018. "Urgensi Uu Kamnas Untuk Antisipasi Masa Depan.” Jurnal Pertahanan \& Bela Negara 6(3):1-18.

Huda, Ni'matul. 2006. "Kedudukan Peraturan Daerah Dalam Hierarki Peraturan Perundang-Undangan.” Jurnal Hukum Ius Quia IusTum 13(1):27-37.

Indarti, Erlyn. 1994. Memasyarakatkan Sistem Kamtibmas Untuk Keperluan Pembangunan. Semarang: Fakultas Ilmu Hukum.

Indrawan, Jerry. 2015. "Relevansi Sistem Pertahanan Negara (Sishanneg) Dengan Konsep Keamanan Nasional Terkait Ancaman Disintegrasi Bangsa Di Papua." Jurnal Polinter: Kajian Politik Dan Hubungan Internasional 1(1):84-96.

Jazuli, Ahmad. 2016. "Pembangunan Pertahanan Dan Keamanan Demi Penegakan Hukum Di Indonesia: Kewibawaan Suatu 
Ladlul Muksinin, Sishankamrata in the Indonesian State Defense...

Negara (Development of Defence and Security for Law Enforcement In Indonesia: A State Authority)." Jurnal Penelitian Hukum De Jure 16(2):187-99.

Kennedy, Posma Sariguna Johnson. 2017. "Pertahanan Indonesia

Dan Pandangan Mengenai Ancaman Serta Ambisi Pada Setiap

Era Kepemimpinan Indonesia." Fundamental Management Journal 2(2):71-76.

Luthfah, Diny. 2016. "Perlindungan Negara Terhadap Keamanan Nasional Indonesia Ditinjau Dari Hukum Internasional: Studi

Kasus Penyadapan Indonesia Oleh Australia.” Jurnal Hukum PRIORIS 4(3):329-47.

Manggala, Pandu Utama. 2016. "Strategi Pertahanan Dan Keamanan Nasional Indonesia.” Jurnal Kajian Lemhanas RI 26.

Mukhtar, Sidratahta. 2017. "Keamanan Nasional: Antara Teori Dan Prakteknya Di Indonesia.” Sociae Polites 127-37.

Nakir, M. 2015. "Kebutuhan Akan Undang-Undang Keamanan Nasional.” Kementerian Pertahanan.

Pemerintah Republik Indonesia. 2020. "Rancangan Undang-Undang Tentang Keamanan Nasional."

Pertahanan, Kementerian. 2015. "Buku Putih Pertahanan Indonesia." Jakarta: Kementerian Pertahanan Republik Indonesia.

Prihatono, T. Hari. 2006. "Penataan Kerangka Regulasi Keamanan Nasional.” Jakarta: Propatria Institute.

Reza, Bhatara Ibnu. 2017. "The Total People's Defense and Security System: Issues Related to State-Sponsored Militia in Indonesia." Indon. L. Rev. 7:155.

Rosikin. 2010. "Proses Penyidikan Tindak Pidana Penyalahgunaan Senjata Api Oleh Anggota TNI Di Denpom IV/4 Surakarta." Universitas Muhammadiyah Surakarta.

Samego, Indria. 2018. "Kontekstualisasi 'Sishanneg': Pemberdayaan Wilayah Pertahanan Dalam Perspektif Perubahan.” Jurnal Pertahanan \& Bela Negara 5(1):1-14. 
Saputra, Helfia and others. 2019. "Implementasi Peraturan Menteri Dalam Negeri Nomor 84 Tahun 2014 Tentang Penyelenggaraan Perlindungan Masyarakat Di Kabupaten Pasaman." Journal Review of Justisia 1(2):22-46.

Setyadi, Arief. 2014. "Jokowi Harus Hati-Hati Susun RUU Kamnas." Okezone.

Siallagan, Haposan. 2016. "Penerapan Prinsip Negara Hukum Di Indonesia.” Sosiohumaniora 18(2):122-28.

Simanjuntak, Efendi Lod. 2020. "Incoming Extradition in Indonesia and Its Implication to Human Rights." Walisongo Law Review (Walrev) 1(2).

Sukmadi, Bambang Heru. 2010. Keamanan Nasional: Sebuah Konsep Dan Sistem Keamanan Bagi Bangsa Indonesia. Sekretariat Jenderal, Dewan Ketahanan Nasional.

Sulistyo, Hermawan and others. 2009. "Keamanan Negara, Keamanan Nasional Dan Civil Society.” Jakarta: Pensil 324.

Susetyo, Heru. 2008. "Menuju Paradigma Keamanan Komprehensif Berperspektif Keamanan Manusia Dalam Kebijakan Keamanan Nasional Indonesia." Lex Jurnalica 6(1):18066.

Suwito, Anton. 2017. "Sishankamrata Sebagai Upaya Peningkatan Ketahanan Nasional Indonesia." in Seminar Nasional KeIndonesiaan II Tahun 2017.

Umra, Sri Indriyani. 2019. "Penerapan Konsep Bela Negara, Nasionalisme Atau Militerisasi Warga Negara." Lex Renaissance 4(1):164-78.

Widjajanto, Andi. 2014. "Kekerasan Militer Di Indonesia." Antropologi Indonesia.

Wijayanti, Winda. 2016. "Eksistensi Undang-Undang Sebagai Produk Hukum Dalam Pemenuhan Keadilan Bagi Rakyat (Analisis Putusan Mahkamah Konstitusi Nomor 50/PUU-X/2012).” Jurnal Konstitusi 10(1):179-204.

Witarti, Denik Iswardani and Semmy Tyar Armandha. 2018. "Tinjauan Teoretis Konsepsi Pertahanan Dan Keamanan Di Era 
Ladlul Muksinin, Sishankamrata in the Indonesian State Defense...

Globalisasi Industri Pertahanan." Jurnal Pertahanan \& Bela Negara 5(3):87-106.

Wulandari, Oktavia, Ali Imron, Briliyan Ernawati, and Nazar Nurdin. 2020. "Presumption of Innocence Against Criminal Offenders in the Police: A Critical Study." Walisongo Law Review 2(1):1738.

Yanti, Bayu Vita Indah. 2014. "Peningkatan Kapasitas Nelayan Terkait Upaya Pertahanan Negara Di Wilayah Perbatasan." Jurnal Kebijakan Sosial Ekonomi Kelautan Dan Perikanan 4(1):15-24. 